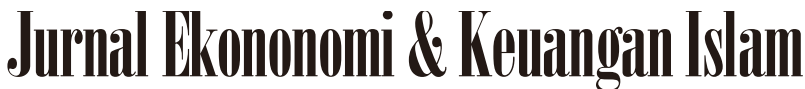

Available at http://journal.uii.ac.id/index.php/jeki

\section{Pengaruh Efisiensi Usaha, Risiko Keuangan dan Kepercayaan Masyarakat terhadap Kemampuan Penyaluran Pembiayaan pada Bank Umum Syariah di indonesia Tahun 2011-2014}

\author{
Fitri Astuti \\ STEBI Global Mulia Jakarta \\ e-mail: fiazmemory@gmail.com
}

\begin{tabular}{l} 
Keyword: \\
$F D R, C R, D P K$ \\
\hline DOI: \\
10.20885/JEKI.vol2.iss2.art2 \\
\hline
\end{tabular}

\begin{abstract}
This study analyzes the Influence of Efficient Enterprises, Financial Risk and Trust Society Against Distribution Financing of Indonesian Islamic Banks in 2011-2014. Based on purposive sampling method, eight sharia banks included in this research. Analysis model used in this study is panel data regression analysis model using. The results showed that partially the NPM have a negative effect and no significant effect on FDR and LR has a positive effect and not significant to FDR, then the variable ROA has a positive and significant effect on the FDR, ROA has a negative and significant effect on the FDR, CR has a positive and significant effect on the FDR, CPR has a positive and significant effect on the FDR and the last DPK has a negative and significant effect on the FDR.
\end{abstract}

\begin{abstract}
Abstrak
Studi ini menganalisis pengaruh efisiensi usaha, risiko keuangan dan kepercayaan masyarakat terhadap distribusi pembiayaan Bank Syariah Indonesia di tahun 2011-2014. Berdasarkan metode purposive sampling, delapan bank syariah termasuk dalam penelitian ini. Model analisis yang digunakan dalam penelitian ini adalah model analisis data regresi. Hasil penelitian menunjukkan bahwa secara parsial NPM memiliki pengaruh negatif dan tidak berpengaruh signifikan terhadap FDR dan LR berpengaruh positif dan tidak signifikan terhadap FDR. Selanjutnya variabel ROA memiliki nilai positif dan signifikan terhadap FDR, ROA memiliki efek negatif dan signifikan terhadap FDR, CR memiliki efek positif dan signifikan terhadap FDR, CPR memiliki efek positif dan signifikan terhadap FDR. Terakhir DPK memiliki efek negatif dan signifikan terhadap FDR.
\end{abstract}

\section{Pendahuluan}

Perkembangan perekonomian moderen saat ini dibutuhkan suatu lembaga yang memiliki peranan besar dalam meningkatkan perkembangan ekonomi suatu negara. Salah satu lembaga keuangan yang mempunyai peranan meningkatkan perekonomian adalah perbankan. Adanya perbankan syariah menjadi solusi alternatif bagi masyarakat muslim yang ingin berinvestasi atau menitipkan uangnya melalui lembaga keuangan yang menggunakan prinsip syariah sebagai landasan hukum untuk menjalankan kegiatan usahanya dimana perbankan memiliki fungsi utama yaitu sebagai lembaga intermediasi antara masyarakat yang kelebihan dana dengan masyarakat yang membutuhkan dana.

Bank menerima simpanan uang dari masyarakat (dana pihak ketiga) kemudian uang tersebut dikembalikan lagi kepada masyarakat dalam bentuk pembiayaan. Pembiayaan yang disalurkan kepada masyarakat mempunyai fungsi penting bagi masyarakat maupun bagi bank. Masyarakat yang membutuhkan dana memperoleh modal usaha atau bentuk pembiayaan, sedangkan bank memperoleh nisbah dari pembiayaan yang diberikan, selanjutnya bagi perkonomian secara keseluruhan akan menggerakan roda perekonomian. Menurut Muhammad (2002) Rasio Financing to Deposit Ratio (FDR) adalah perbandingan antara pembiayaan yang diberikan oleh bank dengan dana pihak ketiga yang berhasil dikerahkan oleh bank, dan menurut Dendawijaya (2003), FDR (financing Deposit to Ratio) adalah rasio antara seluruh jumlah pembiayaan yang diberikan kepada nasabah dengan dana diterima bank. Menurut Asosiasi Perbankan Syariah Indonesia (Asbisindo), idealnya bank syariah memiliki FDR 80\%-90\%. Batas toleransi FDR perbankan syariah sekitar $90 \%$, hal ini dimaksudkan agar likuiditas bank syariah tetap terjaga. FDR perbankan syariah yang tinggi (diatas $100 \%$ ) akan menjadi ancaman serius bagi likuiditas bank syariah itu sendiri. Dengan demikian, FDR dapat digunakan untuk mengukur jumlah dana pihak ketiga yang di salurkan dalam bentuk pembiayaan.

Demikian pula halnya pertumbuhan pembiayaan pada kelompok UUS yang turun dari $85,3 \%$ menjadi $33,5 \%$, serta pertumbuhan pembiayaan BPRS yang turun dari $32,8 \%$ menjadi $24,8 \%$ pada periode yang sama. Perlambatan yang terutama dialami sejak semester kedua 2013 antara lain dipengaruhi ketatnya likuiditas 
sumber dana pembiayaan seiring kontraksi moneter, ekspektasi kenaikan risiko kredit, dan implementasi kebijakan prudensial seperti Financing To Value (FTV) dan down payment pembiayaan konsumsi.

Alokasi penyaluran pembiayaan terjadi baik dalam bentuk pembiayaan kepada sektor-sektor produksi yang diindikasikan oleh pembiayaan modal kerja dan investasi, maupun dalam bentuk pembiayaan bagi rumah tangga (household) yang diindikasikan oleh pembiayaan konsumsi. Sebagaimana pada perbankan konvensional, penguatan fokus perbankan syariah pada pembiayaan sektor produktif mendorong kenaikan pembiayaan modal kerja dan investasi BUS dan UUS sebesar Rp 22,7 triliun, atau tumbuh 27,5\% (yoy). Sementara itu pertumbuhan pembiayaan konsumsi BUS dan UUS mengalami penurunan yang cukup signifikan, dari 50,6\% (yoy) tahun 2012 menjadi 21,4\% pada posisi laporan, antara lain dipengaruhi oleh penerapan Financing To Value (FTV) dan down payment pada pembiayaan kepemilikan rumah dan kendaraan bermotor.

Melihat kodisi perkembangan bank tersebut dengan banyaknya bank yang ada dan banyaknya produk dan jasa yang ditawarkan, dapat menimbulkan berbagai permasalahan. Salah satu permasalahan tersebut bisa mengenai bagaimana kualitas pada bank-bank tersebut dalam melayani masyarakat. Maka penilaian mengenai efisiensi usaha perbankan menjadi penting, dalam memberikan gambaran mengenai kinerja dari masing-masing bank tersebut.

Efisiensi usaha dapat diterjemahkan sebagai kemampuan suatu organisasi dalam menyelesaikan pekerjaan dengan benar dengan perhitungan rasio perbandingan antara input dan output. Dengan kata lain efisiensi adalah bagaimana menggunakan input yang minimal dengan menghasilkan output yang semaksimal mungkin. Tingkat efisiensi bank menggambarkan kemampuan manajemen bank tersebut dalam mengelola seluruh sumber daya milik bank. Semakin efisien usaha bank semakin besar kemampuan bank dalam memperolah keuntungan. Apabila bank tidak mengelola usahanya dengan baik akan mempengaruhi tingkat penyaluran pembiayaan yang diberikan bank kepada masyarakat dan bank yang efisien akan memberikan sinyal positif terhadap kesehatan bank tersebut.

Masalah bank selanjutnya terdapat pada risiko keuangan dimana Bank menyediakan fasilitas yang mampu memberikan kemudahan kepada publik sebagai nasabahnya untuk memperlancar segala urusannya yang menyangkut masalah keuangan. Kemudahan dalam menarik kembali dana dalam jumlah yang disesuaikan, kemudahan dalam mencairkan kredit atau pembiayaan termasuk biaya administrasi yang ditanggung, dan memperhitungkan yang dilakukan secara tepat, cepat dan akurat. kesalahan manajemen perusahaan dapat berakibat fatal terhadap kesulitan keuangan bahkan kegagalan usaha perbankan, sehingga akan mengakibatkan implikasi negatif terhadap kegiatan perekonomian nasional dan merugikan masyarakat sebagai pemilik dana. Berbagai risiko tersebut dapat dilihat dengan mengukur tingkat risikonya dengan menghitung liquidity risk, credit risk/non performing loan (NPF), capital risk dan berbagai elemen-elemen lain suatu bank.

Kepercayaan masyarakat atau dana pihak ketiga sangat dibutuhkan bank untuk menjalankan operasinya. dana pihak ketiga merupakan dana yang dihimpun oleh bank yang berasal dari masyarakat dalam arti luas, meliputi masyarakat individu, maupun badan usaha, bank menawarkan produk simpanan kepada masyarkat dalam menghimpun dananya (Ismail, 2010). Pertumbuhan dana pihak ketiga akan mengakibatkan pertumbuhan penyaluran pembiayaan yang pada akhirnya FDR juga akan meningkat dan sebaliknya menjadi masalah apabila bank dalam usaha penyaluran pembiayaan yang mana bank menjadi media intermediasi terganggu, akan menimbulkan kerugian bagi bank dan juga masyarakat luas.

Banyak penelitian yang telah mengakaji aspek penyaluran pembiayaan perbankan syariah. Salah satunya adalah penelitian yang dilakukan oleh Fikriati (2015), yang meneliti pengaruh Dana Pihak Ketiga (DPK), Non Performing Financing (NPF) dan Inflasi terhadap Financing toDeposit Ratio (FDR) pada bank pembiayaan rakyat syariah di Indonesia. Hasil penelitian menunjukkan bahwa Dana Pihak Ketiga (DPK) memiliki pengaruh signifikan terhadap Financing to Deposit Ratio (FDR), sedangkan Non Performing Financing (NPF) dan Inflasi tidak memiliki pengaruh yang signifikan terhadap Financing to Deposit Ratio (FDR) pada Bank Pembiayaan Rakyat Syariah di Indonesia periode 2010 hingga 2013.

Penelitian yang dilakukan oleh Wahyudi (2013) tentang Analisis Pengaruh CAR, ROA, NPL dan BOPO Terhadap LDR Pada Bank Umum Go Public di Indonesia Periode 2008-2012. Dari hasil pengujian yang dilakukan dalam penelitian ini diketahui secara simultan variabel independen CAR, ROA, NPL, dan BOPO berpengaruh terhadap variabel dependen LDR. Begitu pula penelitian yang dilakukan oleh Penelitian yang dilakukan oleh Hersugondo \& Tamtomo (2012) tentang Pengaruh CAR, NPL, DPK dan ROA terhadap LDR Perbankan Indonesia. Berdasarkan hasil penelitian ditemukan bahwa selama periode penelitian secara parsial, variabel Capital Adequancy Ratio dan Return On Asset berpengaruh positif dan signifikan terhadap LDR perusahaan, Non Performing Loan berpengaruh negatif dan signifikan terhadap LDR perusahaan, sedangkan Dana Pihak Ketiga tidak berpengaruh terhadap LDR perusahaan.

Peneliti lain membahas tentang penyaluran pembiayaan atau kredit yang di teliti oleh Satria \& Subegti (2010) tentang Determinasi penyaluran kredit Bank Umum di Indonesia periode 2006-2009. Adapun variabel yang diuji meliputi ROA, NPL, BOPO, CAR, DPK, Penempatan dana pada SBI dan Market Share, hasil yang 
diperoleh menunjukkan bahwa CAR dan ROA berpengaruh positif terhadap penyaluran kredit bank umum di Indonesia, SBI berpengaruh negatif terhadap penyaluran kredit bank umum di Indonesia, sedangkan NPL, BOPO dan DPK tidak berpengaruh terhadap penyaluran kredit bank umum di Indonesia. Selanjutnya penelitian yang dilakukan oleh Sarie (2011) tentang Pengaruh Faktor Efesiensi Usaha, Risiko Keuangan, Kepercayaan Masyarakat dan Skala Bank Terhadap Kemampuan Penyaluran Kredit Bank Komersial. Kesimpuan dalam penelitian ini ialah BOPO, NIM, Liquidity Risk, Credit Risk, Capital Risk, Kepercayaan masyarakat, dan Skala bank berpengaruh terhadap LDR dan hanya ICR yang tidak berpengaruh terhadap LDR. Berbeda hal dengan penelitian yang dilakukan oleh Sarie (2011) dan Fikriati (2015) dalam penelitiannya Dana Pihak Ketiga (DPK), Non Performing Financing (NPF) NIM, Liquidity Risk, Credit Risk, Capital Risk, Kepercayaan masyarakat, dan Skala bank berpengaruh terhadap LDR atau FDR dan Inflasi tidak memiliki pengaruh yangsignifikan terhadap FDR.

Dari beberapa penelitian di atas, dapat dilihat bahwa penelitian-penelitian tersebut terdapat perkembangan fluktuatif dengan keadaan bank, dilihat dari penelitian Satria \& Subegti (2010) menunjukan bahwa NPL, BOPO dan DPK tidak berpengaruh terhadap penyaluran kredit bank umum di Indonesia. Padahal sumber pendanaan terbesar dalam penyaluran pembiayaan ialah DPK, lalu penyaluran dana sangat sensitif terhadap NPL dan BOPO pada teorinya semakin rendah tingakat rasio BOPO berarti semakin baik kinerja manajemen bank tersebut, karena lebih efisien dalam mengunakan sumber daya yang ada.

Melihat kondisi tersebut maka peneliti tertarik untuk menelaah kembali dengan objek Bank Umum Syariah, dimana bank sangat riskan terhadap gejolak ekonomi dikarenakan bank umum syariah merupakan entitas ekonomi yang sangat rentan terhadap krisis ekonomi dan juga media lembaga keuangan yang sangat dekat dengan masyarakat dan juga menarik bagi investor, mengingat fungsinya sebagai intermediasi dalam penyaluran pembiayaan.

\section{Metode Analisis Data}

Penelitian ini menggunakan regresi data panel. Data panel adalah data yang melibatkan data crosssection dan data time series. Data dikumpulkan dalam satu rentang waktu terhadap banyak individu (Yaffee, 2003).

Variabel dependen dalam penelitian ini adalah variabel Financing to Deposit Ratio (FDR). Penyaluran pembiayaan yang merupakan fungsi intermediasi bank yang biasanya diukur dengan financing to deposit ratio. Menurut Dendawijaya (2003) FDR (Financing Deposit to Ratio ) adalah rasio antara seluruh jumlah pembiayaan yang diberikan kepada nasabah dengan dana diterima bank. Tingginya rasio Financing to Deposit Ratio (FDR) ini, di satu sisi menunjukkan pendapatan bank yang semakin besar, tetapi menyebabkan suatu bank menjadi tidak likuid dan memberikan konsekuensi meningkatnya risiko yang harus ditanggung oleh bank, berupa meningkatnya jumlah Non Performing Loan/Financing atau Credit Risk, yang mengakibatkan bank mengalami kesulitan untuk mengembalikan dana yang telah dititipklan oleh nasabah. Abduh dan Omar (2012) juga menggunakan variabel ini sebagai pengukuran kinerja perbankan syariah.

Selanjutnya, variabel independen meliputi Return on Assets (ROA), Net Profir Margin (NPM), (Liquidity Risk) (LR), Credit Risk (CR), Capital Risk (CPR) dan Dana Pihak Ketiga (DPK). Return on Assets (ROA) merupakan bagian dari analisis rasio profitabilitas. Menurut Kasmir (2012) ROA adalah rasio yang menunjukan hasil (return) atas jumlah aktiva yang digunakan dalam perusahaan. Selain itu, ROA memberikan ukuran yang lebih baik atas profitabilitas perusahaan karena menunjukan efektivitas manajemen dalam menggunakan aktiva untuk memperoleh pendapatan.

Biaya Operasional terhadap Pembiayaan Operasional (BOPO) menurut Dendawijaya (2003), yang di ambil dari kamus keuangan BOPO adalah kelompok rasio yang mengukur efektivitas operasional suatu perusahaan dengan jalur membandingkan satu terhadap lainnya. Berbagai angka pendaptan dan pengeluaran dari laporan rugi laba dan terhadap angka-angka dalam neraca. Rasio biaya operasional digunakan uantuk mengukur tingkat efisiensi dan kemampuan bank dalam melakukan kegiatan operasi.

Menurut Kasmir (2012) Net Profit Margin (NPM), merupakan rasio yang digunakan untuk mengukur margin laba atas penjualan, rasio ini akan menggambarkan penghasilan bersih perusahaan berdasarkan total penjualan. Pengukuran rasio dapat dilakukan dengan cara membandingkan laba bersih setelah pajak dengan penjualan bersih. Nilai NPM dikatakan baik apabila lebh dari 5\% (Sulistyanto, 2008). Semakin tinggi net profit margin semakin besar tingkat profitabilitas yang dicapai oleh bank.

Resiko utama yang dihadapi sebuah bank adalah resiko kredit (credit risk) (How, dkk, 2005). Resiko kredit merupakan rasio untuk mengukur risiko terhadap kredit yang disalurkan dengan membandingkan kredit macet dengan jumlah kredit yang disalurkan (Kasmir, 2012). Risiko kredit merupakan suatu cerminan dari beberapa kredit-kredit yang bermasalah atau yang dikenal dengan istilah NPL (Non Performing Loan). Teori mengatakan bahwa semakin tinggi rasio ini maka kemungkinan bank mengalami permasalahan kegagalan sangat tinggi pula (positif)(Santoso, 1996). 
Capital risk adalah mengukur sejauh mana penurunan yang terjadi pada asset risk dapat ditutupi oleh equity capital yang tersedia. Dikatakan asset risk karena setiap aset mengandung risiko kerugian dan setiap kerugian akan mengakibatkan pengurangan terhadap capital dan apakah capital uang tersedia mampu menampung kerugian tersebut (Muljono, 1995). Tujuannya, untuk mnegukur kemampuan bank menyangga risiko kegagalan bank membayar pengembalian simpanan nasabah dengan modal sendiri, karena rasio ini merupakan perbandingan antara ekuitas terhadap risk asset yang meliputi total aktiva dikurangi kas, giro Bank Indonesia, dan surat berharga.

Variabel independen selanjutnya adalah kepercayaan masyarakat. Kepercayaan masyarakat dalam penelitian ini dinyatakan dengan dana pihak ketiga. Dana pihak ketiga sangat dibutuhkan bank untuk menjalankan operasinya. Dana pihak ketiga biasanya lebih dikenal dengan dana masyarakat, dana pihak ketiga merupakan dana yang dihimpun oleh bank yang berasal dari masyarakat dalam arti luas, meliputi masyarakat individu, maupun badan usaha, bank menawarkan produk simpanan kepada masyarakat dalam menghimpun dananya (Ismail, 2010). Dana pihka ketiga meliputi tabungan giro, tabungan dan deposito.

$$
\begin{aligned}
\ln F D R_{i t}=\beta_{0}+ & \beta_{1} \ln B O P O_{1 i t}+\beta_{2} \ln R O A_{2 i t}+\beta_{3} \ln N P M_{3 i t}+\beta_{4} \ln L R_{4 i t}+\beta_{5} \ln C R_{5 i t}+\beta_{6} \ln C P R_{6 i t} \\
& +\beta_{7} \ln D P K_{7 i t}+e_{i t}
\end{aligned}
$$

$\operatorname{lnFDR} R_{\text {it }}$ merupakan bentuk log natural dari nilai perhitungan Financing Deposit Rasio (FDR) sebanya $i$ dalam waktu $t$. Ln BOPO merupakan bentuk log natural besarnya biaya operasional terhadap pembiayaan operasional (BOPO). Ln ROA bentuk log natural dari Return on Assets, In NPM bentuk log natural dari Net Profit Margin, In $L R$ bentuk log natural dari liquidity risk yaitu resiko likuitas. Ln CR adalah bentuk log natural dari credit risk, ln $C P R$ bentuk $\log$ natural capital risk dan $\ln D P K$ adalah log natural dari dana pihak ketiga. Nilai $e$ merupakan residual dari persamaan regresi tersebut. Ada tiga uji yang digunakan untuk menentukan teknik yang paling tepat untuk mengestimasi regresi data panel, yaitu common effect, random efect, dan fixed effect. Dari pengujian masing-masing model tersebut akan ditentukan model mana yang paling baik dalam menjelaskan persamaan regresi di atas.

\section{Hasil dan Pembahasan}

Setelah dilakukan pengujian untuk mendapatkan model berikut ini, yang merupakan perbandingan antara kedua output :

Tabel 1. Perbandingan Model Random Effect Dengan Model Fixed Effect

\begin{tabular}{lrr}
\hline Model & $\begin{array}{c}\text { Random } \\
\text { effect }\end{array}$ & Fixed Effect \\
\hline$R$-squared & 0.1799 & 0.3664 \\
X1(bopo) & -0.0241 & 0.7864 \\
X2(ROA) & -0.7155 & -1.671 \\
X3(NPM) & 0.2568 & -0.3055 \\
X4(LR) & 0.1388 & 0.7932 \\
X5(CR) & 0.7513 & 1.7238 \\
X6(CPR) & 1.3195 & 2.0726 \\
X7(DPK) & -0.6871 & -0.7948 \\
\hline
\end{tabular}

Sumber : Data diolah

Dalam pengujian yang dilakukan sebelumnya, estimasi parameter dalam data panel menurut Uji Hausman akan lebih tepat jika menggunakan efek random, namun karena tidak memberikan interprestasi yang lebih baik dibandingkan dengan output efek tetap, maka digunakan model efek tetap. Alasan ini juga didukung oleh artikel dan jurnal mengenai penggunaan model efek tetap pada analisis kebijakan. Menurut Buddelmeyer, Oguzoglu dan Webster (2008) dalam jurnalnya yang berjudul "Fixed Effect Bias in Panel Data Estimator" menyatakan bahwa efek tetap akan menjadi hal yang penting dalam implikasi kebijakan.

Model yang digunakan dalam penelitian ini adalah fixed effect model. Seperti telah kita ketahui dalam Fixed Effect, perbedaan karakteristik individu dan waktu diakomodasikan pada intercept sehingga intercept dari setiap perusahaan berbeda-beda begitu juga dengan konstanta yang dimiliki berbeda-beda. Sehingga persamaan model secara individu berbeda. 


\section{Perbandingan Model Fixed Effect dan Model Fixed Effect Cross-section Weight}

Model yang digunakan dalam penelitian ini adalah fixed effect model sehingga perlu dilakukan analisa data lebih lanjut guna menetapkan apakah dalam model terdapat permasalahan heteroskedastisitas. Dalam analisa ini akan dilakukan perbandingan antara Model Fixed Effect dengan Model Fixed Effect Cross-section Weight masingmasing dengan 7 variabel independen.

Model yang terakhir ini mengasumsikan terdapat permasalahan heteroskedastisitas sehingga harus dilakukan adjustment melalui pembobotan pada data cross section. Dengan demikian apabila hasil yang terbaik adalah Model Fixed Effect CrosssectionWeight artinya bahwa terdapat permasalahan heteroskedastisitas namun telah dapat diselesaikan melalui pembobotan pada data cross section.

Tabel 2. Perbandingan ModelFixed Effect dan Fixed Effect Cross-section Weight

\begin{tabular}{lcc}
\hline \multicolumn{1}{c}{ Item } & Fixed Effect & $\begin{array}{c}\text { Fixed Effect Cross- } \\
\text { section Weight }\end{array}$ \\
\hline F-Stat & 0.6609 & 4.5881 \\
R-squared & 0.3664 & 0.8005 \\
C & 5.6991 & 7.5746 \\
X1 BOPO & 0.7864 & 1.8904 \\
X2 ROA & -1.6711 & -2.7201 \\
X3 NPM & -0.3055 & -0.6181 \\
X4 LR & 0.7932 & 1.3808 \\
X5 CR & 1.7238 & 3.1892 \\
X6 CPR & 2.0726 & 3.7948 \\
X7 DPK & -0.7948 & -1.7187 \\
\hline Sumber : Data diolah & &
\end{tabular}

Hasil uji t-stat dengan melihat t-tabel dengan $n=31$ sebesar 1.697 maka out put yang dihasilkan dari model fixed effect menunjukan hanya ada dua variabel yang signifikan $>1.697$ atau menolak Ho yaitu variabel CR dan CPR. Selanjutnya, pada model Fixed Effect Cross-section Weight dimanaberdasarkan uji t-stat ada lima variabel independen yang signifikan $>1.697$ yaitu BOPO, ROA, CR, CPR dan DPK.

Hasil Uji $\mathrm{R}^{2}$ menunjukkan bahwa fixed effect memiliki nilai sebesar 0.366415 atau $36.64 \%$ atau 63 . $35 \%$ dijelaskan oleh variabel lain. Berbeda dengan model Fixed Effect Cross-section Weight yang mempunyai nilai $\mathrm{R}^{2}$ lebih besar yaitu 0.8006 atau $80.06 \%$ dan $19.94 \%$ dijelaskan oleh variabel lain.Dengan demikian dari perbandingan kedua model tersebut diperoleh kesimpulan bahwa model Fixed Effect Cross-section Weight lebih baik bila dibandingkan dengan model Fixed Effect.

\section{Interpretasi Model}

Dari hasil pengolahan data panel menunjukkan bahwa model yang paling baik dalam menjelaskan hubungan antara variabel-variabel independen dengan variabel dependen adalah model Fixed Effect Cross-section Weight. Model tersebut menggunakan 7 variabel independen dengan bentuk model sebagai berikut:

$F D R=2014.767+0.0265$ BOPO $-0.0885 R O A-0.0939 N P M+0.0295 L R+0.0843 C R+0.8982 C P R-0.0244 D P K$

\section{Pengujian Masing-Masing Variabel Bebas Terhadap Penyaluran Pembiayaan (FDR)}

Pengujian ini akan dilakukan dengan dua tahap uji bagi masing-masing variabel bebas pada model penelitian ini, yaitu uji signifikansi dengan $t$-Stat dan uji arah atas nilai koefisiennya.

\section{Variabel BOPO terhadap FDR}

Uji signifikansi yang dilakukan pada variabel bebas dapat dilihat dari nilai t-stat dengan melihat t-tabel dengan $\mathrm{n}=31$ sebesar 1.697. Maka hasil regresi didapatkan bahwa BOPO 1.8904> 1.697 variabel ini berada pada daerah tolak H0. Sehingga dapat diambil kesimpulan bahwa variabel BOPO berpengaruh positif terhadap penyaluran pembiayaan (FDR). 
Kemudian perlakuan atas uji arah untuk menentukan apakah hubungan antara kedua variabel merupakan hubungan yang positif atau negatif dengan melihat koefisiennya. Dari output regresi diatas dapat dilihat bahwa koefisien BOPO bernilai 0.0265. dari angka tersebut dapat diinterpretasikan bahwa hubungan yang terjadi antara BOPO dengan FDR hubungan yang searah/positif. Karena apabila BOPO bank meningkat sebesar $1 \%$ maka nilai FDR bank akan naik sebesar 0.0265 .

\section{Variabel Return on Asset (ROA) terhadap FDR}

Uji signifikansi yang dilakukan pada variabel bebas dapat dilihat dari nilai t-stat dengan melihat t-tabel dengan $\mathrm{n}=31$ sebesar 1.697. Maka hasil regresi didapatkan bahwa ROA -2.7201> 1.697 variabel ini berada pada daerah tolakH0.Sehingga dapat diambil kesimpulan bahwa variabel ROA berpengaruh negatif terhadap penyaluran pembiayaan (FDR).

Kemudian perlakuan atas uji arah untuk menentukan apakah hubungan antara kedua variabel merupakan hubungan yang positif atau negatif dengan melihat koefisiennya. Dari output regresi diatas dapat dilihat bahwa koefisien ROA bernilai -0.0885. Dari angka tersebut dapat diinterpretasikan bahwa hubungan yang terjadi antara ROA dengan FDR hubungan yang searah/ negatif. Karena apabila ROA bank meningkat sebesar $1 \%$ maka nilai FDR bank akan turun sebesar -0.0885 .

\section{Variabel Net Profit Margin (NPM) terhadap FDR}

Uji signifikansi yang dilakukan pada variabel bebas dapat dilihat dari nilai t-stat dengan melihat t-tabel dengan $\mathrm{n}=31$ sebesar 1.697. Maka hasil regresi didapatkan bahwa NPM-0.6181< 1.697 variabel ini berada pada daerah menerima H0.Sehingga dapat diambil kesimpulan bahwa variabel NPM tidak berpengaruh terhadap penyaluran pembiayaan (FDR). Dikarenakan tidak adanya hubungan antara kedua variabel maka analisis mengenai uji arah tidak diperlukan lagi.

\section{Variabel Liquidity Risk (LR) terhadap FDR}

Uji signifikansi yang dilakukan pada variabel bebas dapat dilihat dari nilai t-stat dengan melihat t-tabel dengan $\mathrm{n}=31$ sebesar 1.697. Maka hasil regresi didapatkan bahwa LR $1.3808<1.697$ variabel ini berada pada daerah menerima H0. Sehingga dapat diambil kesimpulan bahwa variabel LR tidak berpengaruh terhadap penyaluran pembiayaan (FDR). Dikarenakan tidak adanya hubungan antara kedua variabel maka analisis mengenai uji arah tidak diperlukan lagi.

\section{Variabel Credit Risk (CR) terhadap FDR}

Uji signifikansi yang dilakukan pada variabel bebas dapat dilihat dari nilai t-Stat dengan melihat t-tabel dengan $\mathrm{n}=31$ sebesar 1.697. Maka hasil regresi didapatkan bahwa CR 3.1892> 1.697 variabel ini berada pada daerah tolak H0. Sehingga dapat diambil kesimpulan bahwa variabel CR berpengaruh positif terhadap penyaluran pembiayaan (FDR).

Kemudian perlakuan atas uji arah untuk menentukan apakah hubungan antara kedua variabel merupakan hubungan yang positif atau negatif dengan melihat koefisiennya. Dari output regresi diatas dapat dilihat bahwa koefisien CR bernilai 0.0843. Dari angka tersebut dapat diinterpretasikan bahwa hubungan yang terjadi antara CR dengan FDR hubungan yang searah/ positif. Karena apabila CR bank meningkat sebesar $1 \%$ maka nilai FDR bank akan naik sebesar 0.0843 .

\section{Variabel Capital Risk (CPR) terhadap FDR}

Uji signifikansi yang dilakukan pada variabel bebas dapat dilihat dari nilai t-Stat dengan melihat t-tabel dengan $\mathrm{n}=31$ sebesar 1.697. Maka hasil regresi didapatkan bahwa CPR 3.7948> 1.697 variabel ini berada pada daerah tolak H0. Sehingga dapat diambil kesimpulan bahwa variabel CPR berpengaruh positif terhadap penyaluran pembiayaan (FDR).

Kemudian perlakuan atas uji arah untuk menentukan apakah hubungan antara kedua variabel merupakan hubungan yang positif atau negatif dengan melihat koefisiennya. Dari output regresi diatas dapat dilihat bahwa koefisien CPR bernilai 0.898186. Dari angka tersebut dapat diinterpretasikan bahwa hubungan yang terjadi antara CPR dengan FDR hubungan yang searah/positif. Karena apabila CPR bank meningkat sebesar 1\% maka nilai FDR bank akan naik sebesar 0.8982 . 


\section{Variabel Dana Pihak Ketiga (DPK) terhadap FDR}

Uji signifikansi yang dilakukan pada variabel bebas dapat dilihat dari nilai t-Stat dengan melihat t-tabel dengan $\mathrm{n}=31$ sebesar 1.697. Maka hasil regresi didapatkan bahwa DPK -1.7187> 1.697 variabel ini berada pada daerah tolak H0. Sehingga dapat diambil kesimpulan bahwa variabel DPK berpengaruh negatif terhadap penyaluran pembiayaan (FDR).

Kemudian perlakuan atas uji arah untuk menentukan apakah hubungan antara kedua variabel merupakan hubungan yang positif atau negatif dengan melihat koefisiennya. Dari output regresi diatas dapat dilihat bahwa koefisien DPK bernilai -0.0244. Dari angka tersebut dapat diinterpretasikan bahwa hubungan yang terjadi antara DPK dengan FDR hubungan yang searah/negatif. Karena apabila DPPK bank meningkat sebesar $1 \%$ maka nilai FDR bank akan menurun sebesar -0.0244.

\section{Analisis Hubungan Masing-Masing Variabel Bebas Terhadap Variabel Terikat}

Analisis regresi yang telah dilakukan bertujuan untuk menginvestigasi hubungan yang dapat diukur dari variabel BOPO, Return on Asset (ROA), Net Profit Margin (NPM), Liquidity Risk (LR), Credit Risk (CR), Capital Risk $(C P R)$, Dana Pihak Ketiga (DPK) pada Penyaluran Pembiayaan (FDR). Tabel 4.7 menunjukkan hasil akhir dari regresi panel data menggunakan metode fixed effect yang mengkonstankan variance menggunakan white heterocedastisity. Pada output dapat dilihat nilai adjusted $\mathrm{R}^{2}$ ialah sebesar 0.8006 yang berarti pada modelregresi ini, variabel bebas dapat menjelaskan variabel FDR terikat delapan bank umum syariah di Indonesia sebesar 80.06\%. Nilai adjusted $\mathrm{R}^{2}$ semakin mendekati 1, maka model ini cukup baik. Dibawah ini merupakan tabel yang merangkum hubungan yang terjadi pada variabel bebas terhadapvariabel terikatnya.

Tabel 3:Tabel Hubungan Variabel Bebas Terhadap Variabel FDR

\begin{tabular}{cccccc}
\hline Variabel & coefficient & t- Statistic & T - tabel & $\begin{array}{c}\text { Hubungan } \\
\text { Yang } \\
\text { Ditemukan }\end{array}$ & Hasil \\
\hline Bopo & 0.0265 & 1.8904 & 1.697 & Positif & Signifikan \\
ROA & -0.0885 & -2.7201 & 1.697 & Negatif & Signifikan \\
NPM & -0.0939 & -0.6180 & 1.697 & Negatif & Tidak signifikan \\
LR & 0.0295 & 1.3808 & 1.697 & Positif & Tidak signifikan \\
CR & 0.0843 & 3.1891 & 1.697 & Positif & Signifikan \\
CPR & 0.8981 & 3.7948 & 1.697 & Positif & Signifikan \\
DPK & -0.0244 & -1.7187 & 1.697 & Negatif & Signifikan \\
\hline
\end{tabular}

Sumber: Hasil output Eviews 6 dan Excel

\section{Efisien Usaha Yang Dinyatakan Dalam BOPO, ROA dan NPM Terhadap Penyaluran Pembiayaan (FDR)}

Dari regresi tersebut dapat dijelaskan bahwa variabel BOPO memiliki koefisien sebesar 0.0265 dengan signifikansi sebesar 1.8904. Hal ini menunjukan bahwa BOPO berpengaruh positif dan signifikan terhadap FDR dengan begitu maka $\mathrm{H}_{\mathrm{a} 1}$ diterima. Tetapi dalam hasil regresi yang peneliti lakukan BOPO memiliki tanda positif yang mana bertentangan dengan teori yang mengatakan apabila BOPO suatu bank rendah maka akan menaikan kemampuan bank dalam menyalurkan pembiayaan. Karena apabila manajemen tidak dapat mengelola biaya operasional terhadap pendapatan operasionalnya maka akan timbulnya biaya operasional yang tinggi dengan studi empiris yang dilakukan oleh Pramono (2006) dengan hasil BOPO berpengaruh negatif terhadap LDR. Data yang terlampir dalam penelitian ini Tabel 4.10 Jaringan Kantor Perbankan Syariah menunjukanpertumbuhan kantor bank umum syariah dari tahun ke tahun mengalami peningkatan jumlah kantor dan dengan pembentukan SDM yang unggul dan handal dapat dilihat di lampiran tabel 4.11 bahwa bank umum syariah terus melakukan perbaikan baik SDM maupun infrastruktur karena mengingat bank umum syariah harus bersaing baik antar bank syariah dan juga bank konvensional.

Dilain sisi bank umum syariah harus menjalankan fungsinya sebagai media intermediasi yakni menghimpun, mengelola dan menyalurkan dana kepada masyarakat pada umumnya. Dengan begitu fungsi sebagai penyaluran pembiayaan harus tetap berjalan meskipun dana operasional yang dikeluarkan bank umum syariah tinggi, bukti dari bank umum syariah dengan biaya operasinal tinggi dan menigkatnya pembiayaan dapat dilihat di lampiran tabel 4.13penyaluran pembiayaan bank syariah pada desember 2014 mengalami peningkatan 8.3\% atau sebesar Rp199.3 triliun dibandingkan pada desember 2013 sebesar Rp184.1 triliun. Berdasarkan sektor ekonomi, pembiayaan terbesar perbankan syariah disalurkan pada sektor jasa dunia usaha sebesar 33.5\%, diikuti sektor perdagangan, restoran, dan hotel sebesar $12.2 \%$. Sementara itu, dilihat dari pertumbuhan 
pembiayaan terbesar terdapat pada sektor pengangkutan, perdagangan dan komunikasi (126\%), serta perindustrian (121\%). Dengan keadaan yng terjadi maka BOPO meningkat mengakibakan FDR pun menjadi menigkat.

Selanjutnya mencermati variabel ROA, variabel ROA memiliki nilai koefisien regresi sebesar -0.0885 dengan signifikansi sebesar -2.7201. Hal ini menunjukan bahwa variabel ROA memiliki pengaruh negatif dan signifikan terhadap FDR. Berdasarkan hasil regresi menunjukan bahwa menerima $\mathrm{H}_{\mathrm{a} 2}$. Tetapi hasil yang ditemukan peneliti ROA bertanda negatif yang mana berbeda dengan teori yang mengatakan bahwa semakin tinggi profiabilitas bank yang tercermin pada rasio ROA maka semakin tinggi pula pembiayaan yang disalurkan (FDR) dan juga hasil penelitian yang dilakukan oleh Satria \& Subegti (2010), dan Huda (2014) menunjukkan bahwa variabel Return On Asset (ROA) berpengaruh positif dan signifikan terhadap Loan to Deposit Ratio (LDR). Tetapi hasil penelitian yang dilakukan oleh Agista A, R (2015) sejalan dengan adanya hubungan negatif. Perbankan syariah sangat dipengaruhi oleh perubahan kebijakan, spekulasi, peraturan, dan lain-lain yang dapat mempengaruhi gejolak keuangan perbankan, oleh karena itu setiap keadaan sangat mempengaruhi manajemen dalam mengambil keputusan untuk menghindari risiko yang terjadi. ROA naik berpengaruh terhadap penurunan pembiayaan bank umum syariah terutama terjadi pada tahun 2013 yang dapat dilihat dalam lampiran tabel 4.14 dikarenakan ketatnya likuiditas sumber dana pembiayaan seiring kontraksi moneter, ekspansi kenaikan risiko kredit dan implementasi kebijakan prudensial seperti Financing to Value dan Down Payment pembiayaan. Sehingga bank umum syariah melakukan sifat kehati-hatian dalam penyaluran pembiayaannya, dengan kata lain meskipun mempunyai profitabilitas tinggi tetapi bank umum syariah harus lebih hati-hati dalam melakukan penyaluran dan lebih selektif. Dengan begitu ROA meningkat berpengaruh negatif atau menurunkan penyaluran pembiayaan bank umum syariah.

Variabel NPM, variabel ini memiliki nilai koefisien -0.0939 dengan nilai t-Stat -0.61801. hal ini menunjukan bahwa variabel NPM tidak signifikan terhadap FDR. Berdasarkan hasil regresi menunjukan bahwa gagal menolak $\mathrm{Ho}_{3}$. Net profit margin (NPM) merupakan rasio yang digunakan untuk mengukur kemampuan manajemen bank dalam mengelola aktiva produktifnya dalam menghasilkan pendapatan bersih. Menurut Dendawijaya (2009), dikatakan bahwa NPM mempunyai pengaruh positif terhadap FDR karena, semakin tinggi Net Profit Margin (NPM) menunjukkan semakin efektif bank dalam penempatan aktiva produktif dalam bentuk penyaluran pembiayaan (FDR). Didukung dengan hasil penelitian yang dilakukan oleh Sarawati (2014) dan Prayudi (2011) bahwa NPM mempunyai pengaruh positif terhadap FDR. Namun, pada bank umum syariah yang dijadikan sampel penelitian ini, ditemukan hubungan negatif dan tidak signifikan terhadap FDR bank umum syariah di Indonesia. Hal ini mengindikasikan bank umum syariah dalam bentuk Net Profit Margin atau pendapatan bersih tidak berpengaruh terhadap penyaluran pembiayaan karena bank umum syariah mempuyai modal yang kuat untuk dijadikan sebagai penyaluran pembiayaan kepada masyarakat.

\section{Risiko Keuangan Yang Dinyatakan Dalam Liquidity Risk, Credit Risk, dan Capital Risk Terhadap Penyaluran Pembiayaan (FDR)}

Selanjutnya variabel Liquidity Risk (LR), variable ini memiliki nilai koefisien 0.0295 dengan nilai t-Stat 1.3808. Hal ini menunjukan bahwa variabel LR tidak signifikan terhadap FDR. Berdasarkan hasil regresi menunjukan bahwa gagal menolak $\mathrm{Ho}_{4}$. Hasil penelitian yang dilakukan oleh Sarie (2011) bahwa koefisienyang negatif menunjukkan jika liquidity risk rendahmaka bank akan semakin rendah menyalurkan pembiayaan kepada masyarakat (FDR). Namun, pada bank umum syariah yang dijadikan sampel penelitian ini, ditemukan hubungan positif dan tidak signifikan terhadap penyaluran pembiayaan (FDR). Hal inimengindikasikan bank umum syariah mengandalkan modal sendiri untuk meng-cover apabila terjadi kegagalan bayar oleh nasabah. Sehingga tidak mempengaruhi penyaluran pembiayaan yang dilakukan oleh bank umum syariah.

Variabel Credit Risk (CR) atau yang biasa disebut dengan rasio Non Performing Financing (NPF), variabel ini memiliki nilai koefisien 0.0843 dengan nilai t-Stat 3.1891.Hal ini menunjukan bahwa variabel $\mathrm{CR}$ memiliki pengaruh positif dan signifikan terhadap FDR.Berdasarkan hasil regresi menunjukan bahwamenerima Hastetapi dalam penelitian ini CR bertanda positif, hal ini tidak sesuai dengan teori bahwa semakin rendah (negatif) tingkat CR maka penyaluran pembiayaan semakin tinggi. Hal ini bertentangan dengan hasil penelitian yang dilakukan oleh Hersugondo (2012), dan Saraswati (2014)menunjukkan bahwa Non Performing Financing (NPF) berpengaruh negatif dan signifikan terhadap penyaluran pembiayaan (LDR). Alasan dari hasil yang didapatkan atas CR yang berpegaruh positif dan signifikan terhadap penyaluran pembiayaan (FDR), karena CR yang terjadi di bank umum syariah masih belum melewatibatas maksimal yang ditentukan oleh bank Indonesia yaitu sebesar 3\% yang artinya masih tergolong cukup sehat. Sehingga walaupun CR yang terjadi pada bank umum syariah dari tahun 2011-2014 meningkat tetapi masih berada dibawah batas yang ditentukan oleh Bank Indonesia maka penyaluran pembiayaan pada bank umum syariah jumlahnya juga meningkat. Hal ini bisa dilihat dari data bahwa DPK yang berhasil dihimpun oleh bank umum syariah dari tahun 2011-2014 terus meningkat sehingga penyaluran pembiayaan (FDR) juga meningkat. 
Variabel Capital Risk (CPR), variabel ini memiliki nilai koefisien 0.8981 dengan nilai t-Stat 3.7948. Hal ini menunjukan bahwa variabel CPR memiliki pengaruh positif dan signifikan terhadap FDR. Berdasarkan hasil regresi menunjukan bahwa $\mathrm{H}_{\mathrm{a} 6}$ terbuktidan sesuai teori yang mengatakan bahwa setiap aset mengandung risiko kerugian dan setiap kerugian akan mengakibatkan pengurangan terhadap capital dan capital uang/modal sendiri tersedia dan mampu menampung kerugian tersebut (Muljono, 1995). Dapat dikatakan capital risk berpengaruh positif terhadap FDR, sehingga penyaluran dana tetap berjalan dan tidak bermasalah karena adanya kegagalan bayar oleh deposan. Hal ini sesuai dengan hasil penelitian yang dilakukan oleh Sarie (2011) dan Sidik (2012) yang menunjukan nilai positif yang ditunjukkan oleh CPR menunjukkan semakin besar rasio modal yang dimiliki oleh bankdapat menutupi kegagalan deposan dalam membayar atas peyaluran pembiayaan yang diberikan bank.

\section{Kepercayaan Masyarakat yang dinyatakan dalam Dana Pihak Ketiga (DPK) Terhadap Penyaluran Pembiayaan (FDR)}

Variabel Dana Pihak Ketiga (DPK), variabel ini memiliki nilai koefisien-0.0244 dengan nilai t-Stat -1.7187. Hal ini menunjukan bahwa variabel DPK memiliki pengaruh negatif dan signifikan terhadap FDR. Berdasarkan hasil regresi menunjukan bahwa gagal menolak $\mathrm{Ho}_{7}$, tetapi dari hasil regresi yang peneliti lakukan ditemukan tanda negatif yang artinya apabila DPK naik maka akan menurunkan penyaluran pembiayaan, berbeda dengan teori dan penelitian sebelumnya yang dilakukan oleh Agista A, R (2015), Lestari (2013) dan Fikriati (2015) yang meyatakan bahwa DPK memiliki pengaruh positif dan signifikan terhadap penyaluran pembiayaan. Sehingga apabila DPK meningkat maka pembiayaan pun juga akan meningkat. Dari temuan tersebut ditemukan karena Bank syariah memiliki alternatif tambahan dalam pengelolaan dana investasinya. Diambil dari Bank Indonesia (BI) Selama tahun 2013, Operasi Moneter Syariah (OMS) yang dilakukan Bank Indonesia (BI) tetap aktif melakukan penyerapan ekses likuiditas perbankan syariah. Secara umum perbankan syariah semakin terdiversifikasi penempatannya di BI baik dalam pemilihan instrumen maupun tenor. Selama tahun 2013 Bank Umum Syariah (BUS) mulai menggeser penempatan dananya ke tenor yang lebih panjang yaitu Reverse Repo (RR) SBSN dan SBIS. Hal ini mendukung strategi lengthening yang dijalankan BI. BI sendiri tetap berkomitmen untuk menyediakan instrumen OMS dengan tenor diantara Deposit Facility Syariah (FASBIS) overnight dan SBIS 9 bulan untuk mendukung OMS.

Perkembangan OMS selama tahun 2013 mengalami peningkatan baik secara posisi akhir tahun maupun secara rata-rata bila dibandingkan dengan tahun 2012. Secara rata-rata tahun 2013 terjadi peningkatan volume OMS sebesar 34,06\%. Peningkatan terbesar untuk rata-rata tahun 2013 terjadi pada instrumen SBIS yaitu sebesar 44,29\%, sedangkan FASBIS yang memiliki share terbesar dalam OMS secara rata-rata tahun 2013 meningkat sebesar 6,06\%. Peningkatan rata-rata OMS selama tahun 2013 tersebut juga diikuti oleh peningkatan posisi OMS per 31 Desember 2013 bila dibandingkan dengan posisi per 31 Desember 2012. Posisi OMS akhir tahun 2013 meningkat sebesar 14,79\% bila dibandingkan posisi akhir tahun 2012.

Selama tahun 2013, Perbankan Syariah mulai menunjukkan kecenderungan untuk menempatkan likuiditas pada instrumen yang bertenor lebih panjang. Hal ini terlihat dari meningkatnya penempatan BUS/UUS pada instrumen RR SBSN yang memiliki tenor 1 bulan dan SBIS yang memiliki tenor 9 bulan. Di sisi lain peningkatan penempatan pada FASBIS hanya meningkat tipis. Sehingga yang terjadi dana pihak ketiga meningkat dan penurunkan penyaluran pembiayaan bank umum syariah terutama ke masyarakat umumnya.

\section{Kesimpulan}

Dari penelitian di atas dapat penulis simpulkan bahwa Pengaruh Efisiensi Usaha, Risiko Keuangan, dan Kepercayaan Masyarakat Terhadap kemampuan Penyaluran Pembiayaan Pada Bank Umum Syariah di Indonesia Pada Tahun 2011-2014 sebaga berikut; variabel BOPO berpengaruh positif dan signifikan terhadap FDR. Hal ini di sebabkan karena bank umum syariah tetap melakukan pembiayaan untuk menutup beban operasial yang tinggi. Hal ini di dukung dengan modal sendiri yang dimiliki bank umum syariah yang cukup kuat untuk mengatasi apabila terjadi resiko.

Variabel ROA memiliki pengaruh negatif dan signifikan terhadap FDR. Hal ini disebabkan karena ketatnya likuiditas sumber dana pembiayaan seiring kontraksi moneter, dan bank umum harus lebih hati-hati dalam penyaluran pembiayaan, dengan kata lain meskipun mempunyai profitabilitas tinggi tetapi tidak ikut serta dalam menaikan penyaluran pembiayaan yang dilakukan oleh bank umum syariah.

Variabel NPM tidak signifikan terhadap FDR. Berdasarkan hasil regresi menunjukan bahwa gagal menolak $\mathrm{Ho}_{3}$. Hal ini mengindikasikan bank umum syariah dalam bentuk Net Profit Margin atau pendapatan bersih tidak berpengaruh terhadap penyaluran pembiayaan karena bank umum syariah mempuyai modal yang kuat untuk dijadikan sebagai penyaluran pembiayaan kepada masyarakat. 
Sedangkan pengaruh risiko keuangan yang dinyatakan dalam Liquidity Risk (LR), Credit Risk (CR), dan Capital Risk (CPR) terhadap penyaluran pembiayaan (FDR). Variabel Liquidity Risk (LR) tidak signifikan terhadap FDR. Berdasarkan hasil regresi menunjukan bahwa bank umum syariah mengandalkan modal sendiri untuk meng-cover apabila terjadi kegagalan bayar oleh nasabah. Sehingga tidak mempengaruhi penyaluran pembiayaan yang dilakukan oleh bank umum syariah.

Variabel Credit Risk (CR) memiliki pengaruh positif dan signifikan terhadap FDR. Berdasarkan hasil regresi menunjukan bahwa menerima $\mathrm{Ha}_{5}$. $\mathrm{CR}$ yang terjadi di bank umum syariah masih belum melewati batas maksimal yang ditentukan oleh bank Indonesia yaitu sebesar 3\% yang artinya masih tergolong cukup sehat. Sehingga walaupun CR yang terjadi pada bank umum syariah dari tahun 2011-2014 meningkat tetapi masih berada dibawah batas yang ditentukan oleh Bank Indonesia maka penyaluran pembiayaan pada bank umum syariah jumlahnya juga meningkat.

Variabel Capital Risk (CPR) memiliki pengaruh positif dan signifikan terhadap FDR. CPR menunjukkan semakin besar rasio modal yang dimilikioleh bankdapat menutupi kegagalan deposan dalam membayar atas peyaluran pembiayaan yang diberikan bank.

Variabel Dana Pihak Ketiga (DPK) memiliki pengaruh negatif dan signifikan terhadap FDR. Hal ini karena Bank syariah memiliki alternatif tambahan dalam pengelolaan dana investasinya sehingga bank umum syariah menempatkan dana tersebut dalam insrtumen SBIS dan yang terjadi dana pihak ketiga meningkat lalu penurunkan penyaluran pembiayaan bank umum syariah.

\section{Daftar Pustaka}

Abduh, Muhamad, dan Omar, M. A. (2012). Islamic Banking and Economic Growth. International Journal of Islamic and Middle Eastren Finance and Management, 5(1), 35-47.

Agista, A. R. (2015). Analisis Pengaruh DPK, CAR, NPF, dan ROA Terhadap Pembiayaan di PT. Bank Muamalat Indonesia Tbk Periode 2007-2013. Solo: Fakultas Ekonomi dan Bisnis, Universitas Muhammadiyah Surakarta.

Buddelmeyer, Dkk. (2008). Fixed Effects Bias in Panel Data Estimators. IZA DP No. 3487.

Dendawijaya Lukman. 2003. Manajemen Perbankan, Edisi Kedua. Jakarta : Ghalia Indonesia.

Fikriati, N. K. (2015). Analisis Pengaruh Dana Pihak Ketiga (DPK), Non Performing Financing (NPF), Dan Inflasi Terhadap Financing To Deposit Ratio (FDR) Bank Pembiayaan Rakyat Syariah (BPRS) Di Indonesia Periode 2010-2013. Jakarta: Fakultas Ekonomi da Bisnis Universitas Negeri Syarif Hidayatullah.

Hersugondo dan Tamtomo. (2012). Pengaruh CAR, NPL, DPK, dan ROA Terhadap LDR Perbankan Indonesia. Dharma Ekonomi No. 36/Th.XIX/Oktober 2012.

How, Janice C. Y, Melina Abdul Karim, Peter Verhoeven. (2005). Islamic Financing and Bank Risks:The Case of Malaysia. Thunderbird International Business Review, Vol. 47(1) 75-94

Huda, G. F. (2014). Pengaruh DPK, CAR, NPL Dan ROA Terhadap Penyaluran Kredit (Studi Pada Bank Umum Yang Terdaftar Di Bursa Efek Indonesia Periode 2009-2012). Semarang: Fakultas Ekonomika dan Bisnis Universitas Diponegoro.

Ismail. (2010). Manajemen Perbankan: Dari Teori Menuju Aplikasi. Jakarta: Kencana Prenada Media Group.

Kashmir, 2000. Manajemen Perbankan. Jakarta: Rajawali Press

Lestari, F. S. (2013). Peranan Kinerja Keuangan Terhadap Besarnya Pembiayaan Perbankan Syariah Di Indonesia. Malang: Fakultas Ekonomi Universitas Islam Negeri Maulana Malik Ibrahim Malang.

Muhammad. (2002). Manajemen Bank Syariah. Yogyakarta: UUP AMP YKPN.

Muljono, T. P. (1995). Analisa Laporan Keuangan untuk Perbankan. Edisi Revisi III. Jakarta: Djambatan.

Pramono, W. (2006). Pengaruh Modal, Likuiditas, dan Efisiensi Terhadap LDR Pada PT. Bank Rakyat Indonesia (Persero) Tbk Periode 2001-2005. Skripsi, Universitas Diponegoro Semarang.

Prayudi, A. (2011). Pengaruh Capital Adequacy Ratio (CAR), Non Performing Loan(NPL), BOPO, Return On Asset (ROA) dan Net Interest Margin(NIM) terhadap Loan to Deposit Ratio (LDR). Master Degree Program - Magister Management, 1. 
Sarie, N.E., (2011). Pengaruh Faktor Efesiensi Usaha, Risiko Keuangan, Kepercayaan Masyarakat dan Skala Bank TerhadapKemampuan Penyaluran Kredit Bank Komersial. Surakarta: Fakultas Ekonomi Univesitas Sebelas Maret

Satria \& Subegti, R. B. (2010). Determinasi Penyaluran Kredit Bank Umum di Indonesia Periode 2006-2009. Jurnal Keuangan dan Perbankan, Vol 14, No.3, September., 7.

Sidik, P. P. (2012). Analisis Pengelolaan Liquidity Risk,Credit Risk Ratio, Deposit Risk Ratio, Capital Ratio, Risk Asset Ratio Terhadap Return On Asset (ROA). Makasar: Jurusan Manajemen Fakultas Ekonomi dan Bisnis Universitas Hasanudin .

Siswati. (2013). Ananlisis Penyaluran Dana Bank Syariah. Dinamika Manajemen Vol. 4, No. 1, 2013 , PP : 82 $92,1$.

Siudek, T. (2008). Theoritical Foundations of Bank Efficiency and Empirical Evidence From Poland. ISSN 1392-3110 Social Research Nr.3 (13), 150-158.

Wahyudi. (2013). Analisis Pengaruh CAR, ROA, NPL, dan BOPO Terhadap LDR Pada Bank Umum Go Public Di Indonesia Periode 2008-2012. Fakultas Ekonomika dan Bisnis, Universitas Diponegoro Semarang.

Yaffee, R. (2003). A Primer for Panel Data Analysis. Connect: Information Technology at NYU, 1-11 